\title{
Evaluation of the haematological parameters in Piaractus mesopotamicus Holmberg (Osteichthyes, Characidae) with Argulus sp. (Crustacea, Branchiura) infestation and treatment with organophosphate
}

\author{
Marcos Tavares-Dias ${ }^{1}$ \\ Maurício Laterça Martins ${ }^{1}$ \\ Sérgio do Nascimento Kronka ${ }^{2}$
}

\begin{abstract}
Haematological parameters as erythrocytes, leukocytes and plasma glucose in Piaractus mesopotamicus Holmberg, 1887 were analyzed. Fish were parasitized with Argulus sp. (Crustacea, Branchiura) and treated with $0.4 \mathrm{mg}$ of thriclorphon 500/L water. The effects of parasitism and the action of the treatment were evaluated. Parasitized fish showed greater number of monocytes $(\mathrm{P}>0.05)$ and special granulocitic cells $(\mathrm{P}<0.01)$ in the peripheric blood than the unparasitized (control) fish. Parasitized fish showed lower number of thrombocytes $(P>0.05)$. Organophosphate treatment presented significantly reduction $(\mathrm{P}>0.05)$ in red blood cells (RBC) and hemoglobin.

KEY WORDS. Piaractus mesopotanicus, Argulus, parasitism, haemathology
\end{abstract}

Haematological studies on Brazilian fishes associated to the parasitism in culture system (RANZANI-PAIVA et al. 1987) or in the nature (RANZANI-PAIVA et al. 1997) are rarely observed. In the present study, the authors compare the effects of the natural parasitism with Argulus sp. (Crustacea:Branchiura) and the response to the organophosphate treatment. Comparison was performed on treated and untreated pacu Piaractus mesopotamicus Holmberg, 1887.

Ten fish with $215.0 \pm 39 \mathrm{~g}$ of body weight and $19.8 \pm 1.1 \mathrm{~cm}$ of length, were collected from a pond at Aquaculture Center - CAUNESP, Jaboticabal, São Paulo State, Brazil. Fish presenting the crustacean Argulus sp. on their body, were maintained in a 250 -litter aquarium.

The ranges of temperature, $\mathrm{pH}$, electric conductivity, and dissolved oxygen were between 27.3 and $28.0^{\circ} \mathrm{C}, 7.5$ and $7.6,186.0$ and $190.0 \mu \mathrm{S} / \mathrm{cm}$ and 4.0 and 4.1 $\mathrm{mg} / \mathrm{L}$, respectively.

Fish were submitted twice to $0.4 \mathrm{mg}$ of thriclorphon $500 / \mathrm{L}$ of water within a two-day interval. In the fifth day, with the aid of a syringe containing EDTA $(10 \%), 1 \mathrm{ml}$ of the blood was collected from the caudal vein.

1) Laboratório de Patologia de Organismos Aquáticos, Centro de Aqüicultura, Universidade Estadual Paulista. Rodovia Carlos Tonanni Km 05, 14870-000 Jaboticabal, São Paulo, Brasil.

2) Departamento de Ciências Exatas, Universidade Estadual Paulista. Rodovia Carlos Tonanni Km 05, 14870-000 Jaboticabal, São Paulo, Brasil. Pesquisador do CNPq. 
Table I. Haematological parameters of Piaractus mesopotamicus parasitized with Argulus sp. before and after treatment with 0,0-Dimetil (1-hidroxi-2,2,2-tricloroetil) phosphate.

\begin{tabular}{|c|c|c|c|c|c|}
\hline \multirow{3}{*}{$\begin{array}{r}\text { Parameters } \\
\operatorname{RBC}\left(10^{3} / \mu \mathrm{l}\right)\end{array}$} & \multicolumn{3}{|c|}{ Untreated } & \multirow{2}{*}{\multicolumn{2}{|c|}{$\frac{\text { Treated }}{\text { Parasitized }}$}} \\
\hline & Control & \multicolumn{2}{|c|}{ Parasitized } & & \\
\hline & $2494.0 \pm 1.0 a$ & $2260.0 \pm$ & $2.5 \mathrm{aA}$ & $1922.0 \pm$ & $1.0 \mathrm{~B}$ \\
\hline Hemoglobin $(\mathrm{g} / \%)$ & $10.4 \pm 1.0 a$ & $9.4 \pm$ & $1.0 \mathrm{aA}$ & $8.2 \pm$ & $0.5 \mathrm{~B}$ \\
\hline Hematocrit (\%) & $29.2 \pm 2.0 a$ & $26.8 \pm$ & $3.5 \mathrm{aA}$ & $25.2 \pm$ & $3.5 \mathrm{~A}$ \\
\hline $\operatorname{MCV}(\%)$ & $117.6 \pm 0.8 a$ & $119.6 \pm$ & $9.0 \mathrm{aA}$ & $133.7 \pm$ & $14.0 \mathrm{~A}$ \\
\hline $\mathrm{MCH}(p g)$ & $41.8 \pm 2.5 \mathrm{a}$ & $42.2 \pm$ & $1.5 \mathrm{aA}$ & $43.4 \pm$ & $1.0 \mathrm{~A}$ \\
\hline $\mathrm{MCHC}(\%)$ & $35.5 \pm 1.5 a$ & $35.5 \pm$ & $3.0 \mathrm{aA}$ & $32.7 \pm$ & $3.0 \mathrm{~A}$ \\
\hline Glucose (mg/dl) & $76.4 \pm 6.5 a$ & $71.8 \pm$ & $5.5 \mathrm{aA}$ & $68.8 \pm$ & $10.0 \mathrm{~A}$ \\
\hline WBC $(\mu \mathrm{l})$ & $1360.0 \pm 233.0 \mathrm{a}$ & $2400.0 \pm$ & $770.0 \mathrm{aA}$ & $2160.0 \pm 6$ & $523.0 \mathrm{~A}$ \\
\hline Thrombocytes (\%) & $82.6 \pm 12.5 a$ & $61.4 \pm$ & $13.0 \mathrm{bA}$ & $61.2 \pm$ & $8.0 \mathrm{~A}$ \\
\hline Lymphocytes (\%) & $12.0 \pm 3.5 a$ & $17.4 \pm$ & $9.0 \mathrm{aA}$ & $15.0 \pm$ & $8.0 \mathrm{~A}$ \\
\hline Monocytes (\%) & $4.2 \pm 0.5 b$ & $13.0 \pm$ & $1.4 \mathrm{aA}$ & $9.6 \pm$ & $2.5 \mathrm{~A}$ \\
\hline Neutrophils (\%) & $1.2 \pm 1.5 \mathrm{a}$ & $6.0 \pm$ & $7.7 \mathrm{aA}$ & $7.0 \pm$ & $4.0 \mathrm{~A}$ \\
\hline SGC $(\%)$ & $0.0 \pm 0.0 \mathrm{~b}$ & $2.2 \pm$ & $1.0 \mathrm{aA}$ & $7.2 \pm$ & $5.0 \mathrm{~A}$ \\
\hline
\end{tabular}

$\left(^{*}\right)$ Mean values followed by the same letter do not differ statiscally by the F-test $(P<0.05)$.

The experimental design was in blocks and each fish was considered an individual block (PIMENTEL GOMES 1985).

Blood smear were stained according to RosENFELD (1947) to differential defense blood cells (leucocytes and trombocytes) counts. Red blood cells (RBC) and white blood cells (WBC) were analyzed in the Neubauer chamber. Hemoglobin and hematocrit determination followed COLLIER (1944) and GOLDENFARB et al. (1971) methods, respectively. Mean corpuscular volume (MCV), mean corpuscular hemoglobin $(\mathrm{MCH})$ and mean corpuscular hemoglobin concentration (MCHC) were evaluated according to the method proposed by WINTROBE (1934). Plasma glucose were analysed according to the enzimatic method (Labtest, Glicose GodAna).

According to the results, Argulus infestation were not significant $(\mathrm{P}>0.05)$ to $\mathrm{RBC}$ and $\mathrm{WBC}$, hemoglobin, hematocrit, $\mathrm{MCV}, \mathrm{MCH}, \mathrm{MCHC}$, plasma glucose, lymphocytes and neutrophils. However, the parasites presence increase monocyte $(\mathrm{P}>0.05)$ and special granolocytic cells number $(\mathrm{SGC})(\mathrm{P}<0.01)$. Infestation decreased thrombocytes number $(\mathrm{P}>0.05)$ as shown in the table I. Similar studies describes significant changes in the blood analysis of parasitized carp, Cyprinus carpio Linnaeus, 1758 (Cyprinidae) (RANZANI-PAIVA et al. 1987). RANZANI-PAIVA et al. (1989) did not observe changes in the plasma glucose. SHIMURA et al. (1983) related significant decrease in the $\mathrm{RBC}$ and $\mathrm{WBC}$, hemoglobin and hematocrit of Oncorhynchus masou Brevoort (Salmonidae) parasitized with $A$. coregoni. These observations were performed for a ten-day period and plasma glucose showed an increase after 24 hours post-infestation. In the present study, pacu showed lower number of thrombocyte, greater number of monocytes and special granulocytic cells.

Organophosphate treatment provoked significant decrease $(\mathrm{P}>0.05)$ in $\mathrm{RBC}$ and hemoglobin. Nevertheless, organophosphate treatment had not effect on the other haematological parameters $(\mathrm{P}>0.05)$ (Tab. I). On the other hand, RANZANIPAIVA et al. (1987) observed a decrease in the MCV, MCHC, leucocytes total count, neutrophills, special granulocytic cells and monocytes in carps (C. carpio). 
Data from this study showed that the variation in the haematological parameters of different fish species may occur and more researches on haematology and other common chemotherapeutics utilized in aquaculture systems must be done.

ACKNOWLEDGMENTS. We would like to thank MSc. Paulo C.F. Carneiro (Centro de Aqüicultura, UNESP, Jaboticabal) for the correction of the translation of the manuscript.

\section{REFERENCES}

COLLIER, H.B. 1944. The standardization of blood haemoglobin determinations.

Can. Med. Ass. Jour. 50: 550-552.

GoldenfarB, P.B.; F.P. BowyeR; Hall \& E. Brosious. 1971. Reproducibility in the hematology laboratory: the microhematocrit determination. Amer. Jour. Clin. Path. 56: 35-39.

Pimentel Gomes, F. 1985. Curso de estatística experimental. Piracicaba, Livraria Nobel, $11^{\mathrm{a}}$ ed., 466p.

RANZANI-PAiVA, M.J.; A.L. ViEIRA \& C.M. Ishikawa. 1989. Análise dos constituintes do plasma sangüíneo da carpa comum Cyprinus carpio, infestada por Argulus sp. B. Inst. Pesca, São Paulo, 16: 117-121.

RANZANI-PAIVA, M.J.; C.M. ISHIKAWA; B.E.S. CAMPOS \& A.C. DAS EIRAS. 1997. Haematological characteristics associated with parasitism in mullets, Mugil platanus Günther, from the estuarine region of Cananéia, São Paulo, Brazil. Revta bras. Zool. 14 (2): 329-339.

RANZANI-PAiVA, M.J.; C.M. ISHIKAWA; M.C. PoRTElla \& R.J. CELIBERTo. 1987. Hematologia da carpa comum Cyprinus carpio, infestada por Argulus sp. e após um tratamento com fosfato de 0,0-dimetil-oxi-2,2,2,-tricloroetilo (Neguvon). B. Inst. Pesca, São Paulo, 14: 83-92.

Rosenfeld, G. 1947. Corante pancrômico para hematologia e citologia clínica. Nova combinação dos componentes do May-Grunwald e do Giensa num só corante de emprego rápido. Mem. Inst. Butantan 20: 329-334.

SHIMURA, S.; K. INOUE; K. KASAI \& H. SAITO. 1983. Hematological changes of Oncohynchus masou (Salmonidae) caused by the infection of Argulus coregoni (Crustacea: Branchiura). Fish Pathol. Univ. Tokyo 18 (3): 157-162.

WINTROBE, M.M. 1934. Variations on the size and hemoglobin content of erythrocytes in the blood various vertebrates. Folia Haematologica. 51: 32-49.

Recebido em 19.XII. 1997; aceito em 29.III.1999. 